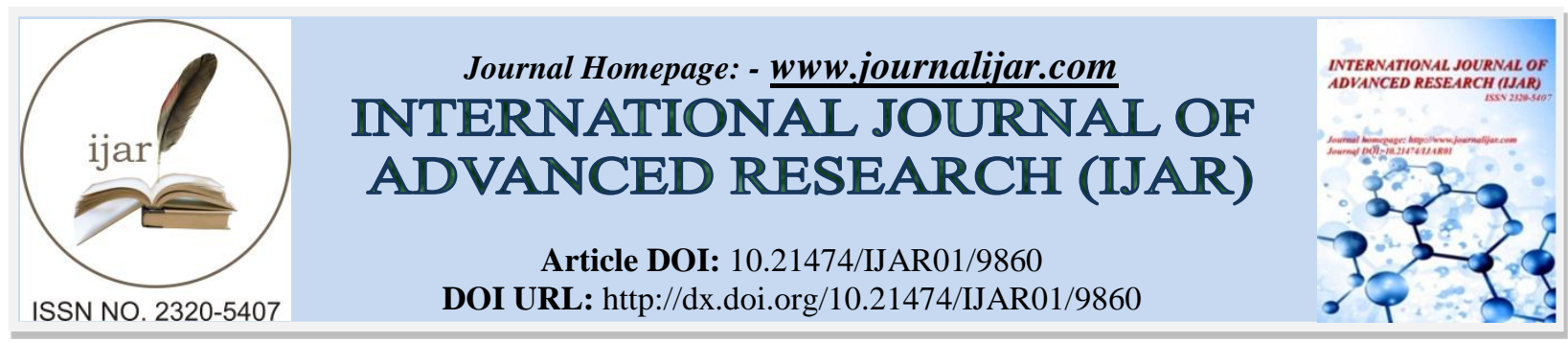

RESEARCH ARTICLE

\title{
POPULATION MIGRANT FROM SUMBERMULYO VILLAGE AND ITS RELATIONSHIP WITH THE ORIGIN AREA.
}

\author{
Lukmono Hadi ${ }^{1}$ and Arif Wibawa ${ }^{2}$. \\ UPN "Veteran" Yogyakarta.
}

\section{Manuscript Info}

\section{Manuscript History}

Received: 08 August 2019

Final Accepted: 10 September 2019

Published: October 2019

Key words:

Migrant, remittance, visit.

\begin{abstract}
This study on the population mobility was done at Sumbermulyo village as a study object. Respondents interviewed in the survey were: (1) family heads whose at least one of their family members exercised mobility following the systematic random sampling, (2) all migrants who were back to home visiting their families. In general the purpose of this study was to find describe about relative links of the origin area-destination area that manifested in remittance forms or visit to the village. In order to describe fully any phenomena in accordance with the investigational purpose being achieved, frecuency distribution, cross tabulation, and multiple regression analysis ara applied. The statistical test ( $\mathrm{t}$ test and $\mathrm{F}$ test criteria) was only carried out as far as for confirming the purposed hypothetical test. The findings in this study in a brief as followed: the migrants were generally young and had relatively high educational level in average. They went out of the village related to the lack of the work opportunity. Their mobility steps spread over Indonesian territory, but generally still in Java Island (almost 75\%), and the cities as the destinations. There are also who went out to other countries, such as Taiwan, Malaysia, and Hong Kong. In general the migrants recoqnized that they could live better than when that they at the villages. Althouhg they had gone out of their village, their relative links manifested in the form of origin area was quite strong. In general they sent remittance and had a visit.
\end{abstract}

Copy Right, IJAR, 2019,. All rights reserved.

\section{Introduction:-}

Cooke \& Belanger (2009) argue that the volume of population mobility increases in line with a country's economic development and tends to increase rapidly if there is a prominent diversity between regions. It seems that this situation is more or less faced by Indonesia in its development. Displacement of population into something that is necessary.

However, the problem of population mobility in Indonesia received less attention, at least compared to the other two demographic components. By Suharso (2007) it was even said that data and research results were still very scarce in questioning the phenomenon of migrant relations with their families in the area of origin. Soon many things will remain unclear. According to him, this is because until now the relationship between migrants and families in the area of origin has received less attention. More expressed in rhetoric than based on data in the field. He suspects

Corresponding Author:- Lukmono Hadi. 
many factors influence the relationship, for example socioeconomic factors, education, marital status, and the distance of the area of origin to the destination

With regard to the problems mentioned above, this study intends to look at the picture of the situation of migrants in general, as well as a description of the bonds that are manifested in the territorial form of kinship from the destination areas, which is manifested in the form of remittances and visits, by limiting themselves to 257 migrants from Sumbermulyo Village.

Through this study it is hoped that knowledge can be obtained about the direction of distribution, moving motivation, relationship motivation, and the factors that most influence these two forms of relationship. From this aspect it is also expected to be able to contribute to decision makers in efforts to bring change to the whole rural area. While academically, it is expected to increase the treasury of studies on mobility, and is expected to be used as a justification or just a critical review of theories about mobility in general.

\section{Literature Review :-}

Conceptually, horizontal or geographical population mobility is a population movement that includes at least two dimensions, namely the dimension of time and place (Gould \& Prothero, 1995). Both dimensions can vary. For the dimensions of a place, for example, can vary from a distance of several meters to miles, for time can vary from a few hours to years.

On the basis of variations in the two dimensions, population mobility is divided into two, namely permanent mobility (migration) and temporary mobility (circulation). Time and place criteria for determining migration or circulation are not uniform. But many experts agree (for example, Ma et al., 1996; Shaw, 1975; Thomlinson, 1999; Gould \& Prothero, 1995) that the time dimension in migration has a connotation that it symbolizes permanent displacement.

In general, the process of migration can be explained through a combination of repellent factors from the area of origin and pull factors from the destination area, but most theories say the factors that cause migration are more due to factors driving from the area of origin.

Norris (2006) for example, says that the factors that cause migration are more due to factors of encouragement from the area of origin, such as pressure or torture in the religious, political, racial and economic fields. Meanwhile, according to Fawcett (1999) a person has 7 orientations in his life, namely: prosperity, status, comfort, stimulation of autonomy, affiliation, and morality. Each person gives value to each of the seven goals in life. Motivation of migration depends on the expectation that life goals will be achieved, namely by staying or migrating. Meanwhile, according to Lewis (1954) in developing countries there is a dualism of the economic system. Subsistence economic systems in most rural areas, and economic systems that exist in cities. The disparity between the two regions results in rural-urban movement.

Relationship of migrants with families in the village of origin. The problem of migrant relations with families in the area of origin can be studied by utilizing micro-studies, such as the Caldwell (1999) study in Ghana, Connell et al., (2005) in India.

The results of their study agreed to say that the genealogical bond that is manifested in the territorial form of the origin areas of destination is real, not something imaginary. Manifestations of relationships which are usually manifested in the form of remittances and visits.

In general, remittances are used to meet the needs of everyday life (Connell et al., 2005). Furthermore, Curson (2011) formulated 6 main objectives for sending remittances, (1) to help families, (2) for life cycle ceremonies, (3) helping families, (4) to pay off debts, (5) for investments, (6) for retirement planning.

In a broader context, where remittances are used for the needs of the wider community can be found in Minangkabau migrants (Naim, 1994).

In terms of visits, many studies reveal that migrants also make time to visit the village of origin (Naim, 1994; Mantra \& Kasai, 1989; Connell et al., 2005; Collier et al., 1974). According to Naim, their visit can be periodic 
(holidays or other holidays) or incidental (usually closely related to important family activities). However, many of the studies mentioned above do not seem to provide information on whether the visit was solely due to attachment to family or because of attachment to ancestral land, or because of other motivations.

Hypothesis formulation is made as a guide to achieve the second research goal. Where the focus is on trying to find relationships between variables. Built by following the direction presumptions that have been shown by Mantra \& Kasai (1989).

First hypothesis.

The size of the remittance varies according to the variety of education, employment, and income.

Second hypothesis.

Among the three factors examined, what really influences the level of retiman is the income of migrants.

\section{Third hypothesis.}

There is a difference in the tendency of migrant visits to families in the village of origin according to the varying distance of the cost of travel, and marital status.

So that all speak in one language, some terms in this study are given understanding and limitations: Migrant, is someone aged 15 years or older who has moved from the area of origin, and has a minimum of 6 months in the destination. Relationships, the meaning is in the sense of familial socioeconomic, and are limited in one direction. Family, the understanding follows the concept of kinship that applies in rural Java, which is usually termed with relatives. Hometown, is a place where migrants are born. Remittance, by definition is money from migrants sent. directly or indirectly to the area of origin. A visit, is to go home for a while.

\section{Method :-}

The study data was mainly obtained from the head of the family of a household where at least one family member migrated. And from migrants going home visiting their families during the data collection period. In this study also conducted personal observations and interviews with informants in the case village.

In this study, an analytical framework model is developed which is a simplification of the second objective to be achieved in this study. The model appears in the following image:

Figure 1:-Figure Of The Research Analysis Framework

Independent variable

\section{Education}

\begin{tabular}{|l|l|}
\hline Jobs & \\
& \\
& \\
\end{tabular}

Dependent variable

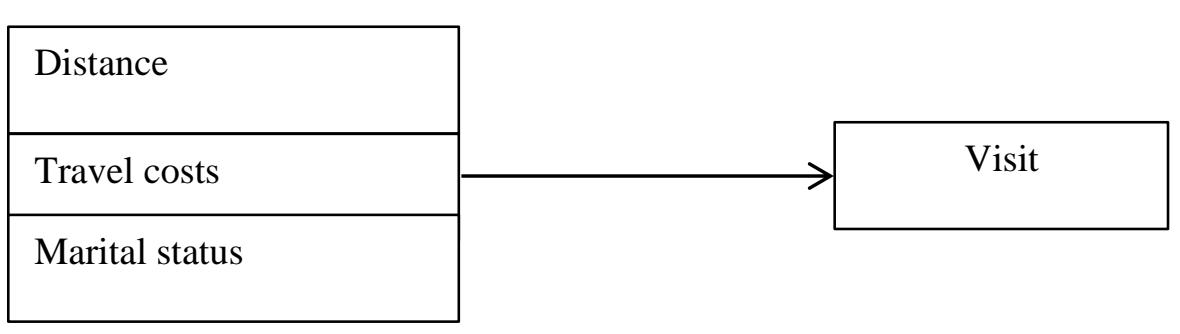


For the sake of hypothesis testing, the 8 variables analyzed were classified into two categories (dichotomized). The first and third hypotheses are tested using the Kai Skwer test. The real limit is used at the level of 5\% and 1\%. Then the second hypothesis is tested with a multiple function linear regression analysis model. Significance test used F test criteria (F test criteria) Anavar Table at $\alpha=5 \%$ and $1 \%$.

\section{Result and Discussion :-}

Migrants in this study appear to exhibit the same characteristics as migrants in general (see for example: Shryock, 2012; Sahin et al., 2005; Caldwell, 2009; Temple, 2011), ie young age (20-30 years), relatively high educated. They migrate more because of the encouragement from the village which is related to economic factors and employment opportunities. And they continue to foster relationships with families in the area of origin which is manifested in the form of remittances and visits.

There are many factors that influence the level of remittance. However, of the three factors (distance, cost, marital status) which in this study are thought to have a large influence on the size of the remittance, it turns out that from the contingency table analysis it is found that only income factors that have a significant effect (evident at $\alpha 0.01$ level) on the size of the remittance .

From the calculation figures obtained through the multiple function linear regression model, and are listed in Table 1 and Table 2 below, it shows that the magnitude of the regression contribution of the three factors studied on the level of remittance is very small. These three factors only explain the remittance rate of 12.1 percent or R2 $=0.121$ (with the $\mathrm{F}$ test criteria, significant at the 0.01 level). And most of the approximately 88 percent can not be explained what causes it in this study.

Table 1:-Influence Of Education, Income, And Jobs In Treatment

\begin{tabular}{|l|c|c|c|l|}
\hline \multicolumn{1}{|c|}{ Type of factor } & Simple $\mathrm{r}$ & Beta & t Score & \multicolumn{1}{|c|}{ Influence } \\
\hline Income (thousands of rupiah) & 0,338 & 0,821 & 4,935 & $* * *$ very influential \\
Education (years of success) & 0,210 & $-0,184$ & $-0,306$ & $* *$ no effect \\
Employment (hours of work) & 0,184 & 0,082 & 1,304 & $*$ no effect \\
Constante $=10,770$ & & & & \\
$\quad \mathrm{R}^{2}=0,121$ & & & & \\
\hline
\end{tabular}

Information:

*) significant at the 0.05 level

**) real at the 0.05 level

***) real at the 0.01 level

The magnitude of other unexplained factors may also have something to do with migrant personal factors that are usually difficult to measure. This factor by Taylor (2007) is called a dynamic variable or a lag variable.

Among the three factors studied, the greatest influence on the level of remittance is the migrant income factor (evident at the 0.01 level). This is evident both in terms of the beta coefficient $(0.821)$ and when viewed from the point of correlation (simple r) of 0.338. Whereas migrant education and migrant employment do not significantly affect remittances. Or it could be said that whatever the education of migrants, and wherever the employment of migrants is, will not affect the difference in remittance values. As a consequence, the second hypothesis proposed in this study was accepted.

Table 2:-Correlation Matrix (R) Variables: Remitants, Education, Job Field, And Income

\begin{tabular}{|l|r|r|r|r|}
\hline Variable & Remittance & Education & Income & Employment \\
\hline Remittance & 1.000 & 0,021 & 0,0338 & 0,187 \\
Education & 0,021 & 1,000 & 0,142 & $-0,069$ \\
Income & 0,338 & 0,142 & 1,000 & 0,232 \\
Employment & 0,187 & $-0,069$ & 0,232 & 1,000 \\
\hline
\end{tabular}

Up to all that has been said, and seeing all the above facts, it is probably correct to say that the income factor is merely giving meaning to variations in the level of remittance. 
In terms of visits to the village of origin, the results of this study show that migrants visit the village of origin an average of 3 times a year. And almost certainly they visited on Lebaran (95\%), then Christmas (40\%), and then Nyadran day $(35 \%)$. And it seems to be a new social phenomenon with quite a number of migrants visiting on the Proclamation Day of August 17 (26\%). This seems to be related to geneaological ties - which are manifested in territorial form - which constitute the majority of the strong enough kinship ties.

While of the three factors (distance, cost, marital status) which in this study were thought to influence the visit it turns out - through cross-table analysis - only the distance factor significantly influences the visit (evident at $\alpha 0.01$ level). But apparently in the case of this study the distance has a negative effect, in the sense that the longer the distance, the more migrants will tend to visit.

\section{Conclusion:-}

In the destination area, migrants continue to foster / establish relationships with family or relatives in the village. The territorial ties of kinship still appear to be quite strong, and are manifested in the form of remittances and visits. The factors that influence remittance and visitation are many, but from the factors that are thought to influence and become hypotheses in this study, then:

1. Variations in remittance rates only differ according to the level of income of the migrant.

2. Of the three influence factors studied, the most determining level of remittance is migrant income.

3. The tendency for village visits only differs by distance. Contrary to the proposed hypothesis, long-distance migrants are more likely to visit than short-distance migrants

All of the above facts lead to a conclusion that emotional factors, such as intention, willingness, and past habits seem to be more dominant in determining the close relationship between migrants and families in the village. So it seems too hasty if someone thinks that the kinship is determined solely by the service factor. What approaches the truth is perhaps the interaction between the two dialectically in a certain situation, condition, and period of time, in a certain place.

Because migrant relations with their families in the village that are manifested in the form of remittances are real, the government can provide facilities for the smooth implementation of remittance flows. For example, a government financial institution or bank (BRI Unit Desa) that has only existed at the Bambanglipuro sub-district level can be considered for opening in Sumbermulyo village, or it is necessary to think of a kind of cooperative that can provide loans that repay through remittances.

\section{Reference:-}

1. Cooke, M., \& Bélanger, D. (2006). Migration theories and First Nations mobility: Towards a systems perspective. Canadian Review of Sociology/Revue canadienne de sociologie, 43(2), 141-164.

2. Caldwell, J. C. (1968). Determinants of rural-urban migration in Ghana. Population Studies, 22(3), 361-377.

3. Collier, W. A., Colter, J., Sinarhadi, \& Shaw, R. D. A. (1974). Choice of Technique in Rice Milling on Java. Bulletin of Indonesian Economic Studies, 10(1), 106-120.

4. Connell, J., Dasgupta, B., Laishley, R., \& Lipton, M. (1976). Migration from rural areas: The evidence from village studies.

5. Curson, P. (1981). Remittances and migration--the commerce of movement. Population geography: a journal of the Association of Population Geographers of India, 3(1-2), 77-95.

6. Fawcett, J. T. (1980). A value-expectancy approach to migration decisions. [Unpublished] 1980. Paper presented at the Population Association of America Annual Meeting Denver Colo. Apr. 10-12 1980.

7. Gould, W. T., \& Prothero, R. M. (1975). Space and time in African population mobility. People on the Move: Studies in Internal Migration. London: Methuen, 39-49.

8. Ma, H. K., Shek, D. T., Cheung, P. C., \& Lee, R. Y. (1996). The relation of prosocial and antisocial behavior to personality and peer relationships of Hong Kong Chinese adolescents. The Journal of Genetic Psychology, 157(3), 255-266.

9. Lewis, W. A. (1954). Economic development with unlimited supplies of labour. The manchester school, 22(2), 139-191.

10. Mantra, I. B., \& Kasai, S. (1987). Population Mobility and Link between Migrants and Family Back Home: A Case Study of Two Villages in Yogyakarta Special Region, Indonesia. Nihon Daigaku.

11. Norris, R. E. (1972). Migration as spatial interaction. Journal of Geography, 71(5), 294-301. 
12. Naim, M. (1979). Merantau: pola migrasi Minangkabau (Doctoral dissertation, Gadjah Mada University Press).

13. Sahin, M., Greer, P. L., Lin, M. Z., Poucher, H., Eberhart, J., Schmidt, S., ... \& Hu, L. (2005). Eph-dependent tyrosine phosphorylation of ephexin1 modulates growth cone collapse. Neuron, 46(2), 191-204.

14. Shaw, R. P. (1975). Migration theory and fact: a review and bibliography of current literature.

15. Suharso. (2007). Pola-perpindahan penduduk dan urbanisasi di Jawa. Faktor-faktor yang mempengaruhi dan dan proses kejadiannya, Dissertation, Universitas Gadjah Mada.

16. Shryock, A. (2012). Breaking hospitality apart: bad hosts, bad guests, and the problem of sovereignty. Journal of the Royal Anthropological Institute, 18, S20-S33.

17. Taylor, J. B. (Ed.). (2007). Monetary policy rules (Vol. 31). University of Chicago Press.

18. Temple, B. (2011). Polish Migrants' Narratives of'Us','Them', Language and Integration'. Post-Accession Migration in Europe-a Polish Case Study. Kraków: Impuls, 39-54.

19. Thomlinson, R. (1965). Population dynamics causes and consequences of world demographic change. 